\title{
Peran Strategi Bisnis Dalam Meningkatkan Keunggulan Bersaing di Industri Fashion
}

\author{
Linda Maryani ${ }^{1 *}$ dan Harmon Chaniago ${ }^{2}$ \\ ${ }^{1}$ Administrasi Niaga, Politeknik Negeri Bandung, Indonesia \\ ${ }^{2}$ Administrasi Niaga, Politeknik Negeri Bandung, Indonesia
}

\begin{abstract}
This research aims to analyze the influence of business strategy in increasing competitive advantage. Selected population is the Creative Industry SMEs in the fashion sector in Bandung, amounting to 507 population in the period 2010-2017 and the number of samples of 223 SMEs fashion business in Bandung. Data collection using questionnaires with Likert scale. Data analysis using Regression Linear with SPSS 22.0. The result of data analysis shows that the research model can be accepted with goodness of fit test, that is effect positive and significant to competitive advantage. In general from the results of model testing applied to SMEs fashion in the city of Bandung the majority use integrated leadership strategies / differentiation through new product innovation, enhancing a different service with competitors, and lower selling price of competitors by becoming low-cost producers, both from the process of raw material costs and distribution costs. Where competitive advantage generated by the company can be improved through product superiority, price, personnel, image, service quality and distribution channels. This study provides some limitations of research and future research agenda that can be done in further research.
\end{abstract}

Keywords: business strategy, competitive advantage, small medium enterprise, fashion industry

Abstrak: Penelitian ini bertujuan untuk menganalisis pengaruh strategi bisnis dalam meningkatkan keunggulan bersaing. Populasi yang dipilih adalah UKM Industri Kreatif di sektor fesyen di Bandung, berjumlah 507 populasi pada periode 2010-2017 dan jumlah sampel sebanyak 223 bisnis fashion UKM di Bandung. Pengumpulan data menggunakan kuesioner dengan skala likert. Analisis data menggunakan Regresi Linear dengan SPSS 22.0. Hasil analisis data menunjukkan bahwa model penelitian dapat diterima dengan uji goodness of fit, yaitu efek positif dan signifikan terhadap keunggulan bersaing. Secara umum dari hasil pengujian model yang diterapkan pada mode UKM di kota Bandung mayoritas menggunakan strategi / diferensiasi kepemimpinan terintegrasi melalui inovasi produk baru, meningkatkan layanan yang berbeda dengan pesaing, dan menurunkan harga jual pesaing dengan menjadi produsen berbiaya rendah, baik dari proses biaya bahan baku dan biaya distribusi. Dimana keunggulan kompetitif yang dihasilkan oleh perusahaan dapat ditingkatkan melalui keunggulan produk, harga, personel, citra, kualitas layanan, dan saluran distribusi. Penelitian ini memberikan beberapa keterbatasan penelitian dan agenda penelitian masa depan yang dapat dilakukan dalam penelitian lebih lanjut.

Kata Kunci: strategi bisnis, keunggulan bersaing, usaha kecil menengah, industri fashion 


\section{Pendahuluan}

\subsection{Latar Belakang}

Lingkungan bisnis memiliki pengaruh besar terhadap kebutuhan masyarakat sehingga dapat memberikan perubahan besar terhadap permintaan masyarakat dan penawaran yang diberikan oleh para pelaku bisnis. Seperti halnya hukum ekonomi semakin tinggi tingkat permintaan suatu barang atau jasa maka tingkat penawaran semakin meningkat. Perubahan kondisi perekonomian dapat menjadi fenomena munculnya suatu strategi bisnis dalam mempertahankan keunggulan bersaing. Berikut merupakan hasil survei BPS mengenai pertumbuhan ekonomi Indonesia:

Berdasarkan hasil survei BPS tersebut menjelaskan bahwa pertumbuhan ekonomi di Indonesia dari tahun 2010-2015 mengalami penurunan yang signifikan. Penurunan ini adalah satunya diakibatkan oleh inflasi, namun di tahun 2015-2017. Perkembangan ekonomi di Indonesia mulai adanya keniakan ke arah yang lebih baik. Pertumbuhan Ekonomi Indonesia mulai membaik pada tahun 2016-2017 dikarenakan banyaknya para investor asing menanam modal di Indonesia dan pembangunan infrastruktur yang cukup baik. Oleh karena itu kontribusi pelaku usaha sektor industri kreatif memiliki peran dalam perubahan pertumbuhan ekonomi nasional yang lebih baik. Salah satu peran yang sederhana dari pelaku bisnis yaitu memenuhi kebutuhan masyarakat dengan mendirikan suatu badan usaha seperti Usaha Mikro Kecil dan Menengah (UMKM).

Banyaknya jumlah UMKM dengan jenis yang sama menuntut para pelaku bisnis untuk dapat melangkah dan memiliki strategi untuk keberhasilan usahanya dalam mengahadapi persaingan yang semakin ketat. Strategi di UMKM dapat ditingkatkan melalui implementasi tingkat strategi bisnis dan sudut pandang dari segala aspek kehidupan secara global. Strategi bisnis di Usaha Mikro Kecil Menengah (UMKM) dapat dilakukan dengan berbagai cara, salah satu caranya yaitu perusahaan atau pelaku bisnis harus memiliki keistimewaan produk yang unik atau belum ada sebelumnya sebagai kreativitas produk baru dan unggul.

Pengembangan UMKM perlu mendapatkan perhatian yang besar, baik dari pemerintah maupun masyarakat agar dapat berkembang lebih kompetitif bersama pelaku ekonomi lainnya. Beberapa faktor baik internal dan eksternal yang mempengaruhi keberhasilan dari usaha kecil dan menengah. Foktor eksternal dapat dilihat dari segi bantuan pajak, hukum dan pertumbuhan ekonomi dari kebijakan pemerintah sebagai tindakan pemberdayan UMKM secara berkesinambungan. Selain faktor ekternal, faktor internal merupakan faktor pendukung utama untuk keberhasilan usaha, faktor internal terdiri dari kemampuan (skill), sumber daya, dan modal. Hal tersebut sangat berpengaruh pada pengelolaan kegiatan bisnisnya. Namun, pada implementasinya sulit untuk berkembang secara optimal.

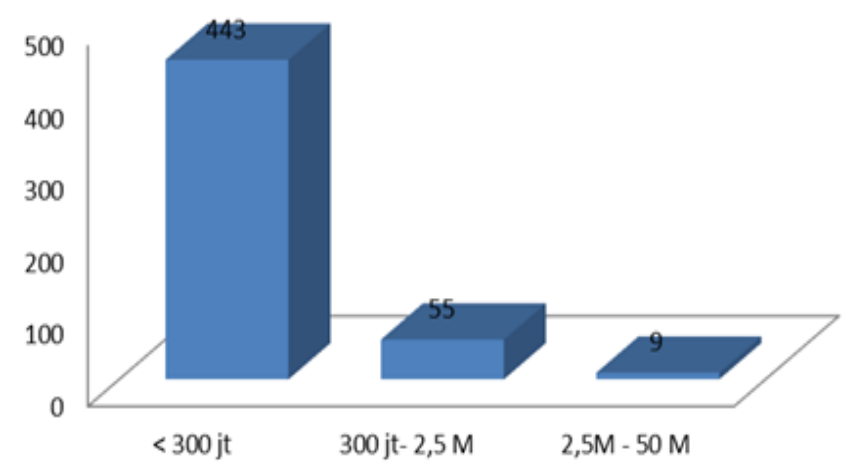

Sumber : Dinas Koperasi dan UMKM Kota Bandung (2018)

Gambar 1. Jumlah UMKM Fashion di Kota Bandaung Periode (2010-2017)

Sebagian besar usaha kecil tumbuh secara tradisional yaitu merupakan usaha keluarg yang turuntemurun dan tidak di kembangkan. Kota Bandung tercatat dengan jumlah UMKM sektor fashion 
sebanyak 507 unit yang tergabung dalam asosiasi UMKM dari jumlah itu, 20\% UMKM tergolong pemula. Berikut merupakan data klasifikasi UMKM sektor fashion di Kota Bandung:

Tabel 1. Klasifikasi UMKM di Kota Bandung

\begin{tabular}{|l|l|l|l|}
\hline \multirow{2}{*}{ No } & \multicolumn{1}{|c|}{ Keterangan } & \multicolumn{2}{|c|}{ Kriteria } \\
\cline { 3 - 4 } & & \multicolumn{1}{|c|}{ Asset } & \multicolumn{1}{c|}{ Omzet } \\
\hline 1 & Usaha Mikro & Max 50 jt & Max 300 jt \\
\hline 2 & Usaha Kecil & $>50 \mathrm{jt} 500 \mathrm{jt}$ & $>300 \mathrm{jt}-2,5 \mathrm{jt}$ \\
\hline 3 & Usaha Menengah & $500 \mathrm{jt}-10<$ & $>2,5 \mathrm{M}-50 \mathrm{M}$ \\
\hline
\end{tabular}

Sumber: Undang-Undang Nomor 20 Tahun 2008

Adapun dasar pertimbangan dilalukannya penelitian pada Usaha Kecil dan Menengah (UMKM) pada sektor fashion, karena usaha ini cukup strategis untuk meningkatkan kesejahteraan masyarakat disekitarnya. Industri kreatif sektor fashion di Kota Bandung menjadi sebuah ikon yang baik dengan terkenalnya sebagai "Kota Paris Van Java". Hal tersebut terbukti dengan peningkatan jumlah mall, distro, factory outlet dan banyaknya fashion even di Kota Bandung dengan nama kegiatan yang telah terselenggara seperti Trade Mark, Kick Fest, Fashionary dan lain sebagainya dapat memberikan daya tarik pengunjung luar kota maupun pengunjung mancanegara.

Fenomena yang ditemukan di lapangan melalui proses wawancara dan menurut hasil penelitian terdahulu. Fenomena yang pertama banyak para pelaku bisnis di UMKM sektor fashion di Kota Bandung tidak mengeksplor produk-produk lokal secara maksimal. Fenomena kedua pada UMKM sektor fashion di Kota Bandung memerlukan sebuah wadah untuk menuangkan ide-ide kreatif agar terintegrasi dengan baik seperti halnya adanya fungsi pengawasan untuk perubahan dan perkembangan dunia fashion secara global sehingga dapat dievaluasi setiap kegiatan bisnis yang sedang berjalan dalam mengahadapi persaingan yang lebih sengit di masa yang akan datang. Fenomena ketiga adanya penurunan daya beli masyarakat. Penurunan daya beli masyarakat tersebut dirasakan sebagian besar para pelaku usaha UMKM mulai tahun 2016 hingga sekarang. Hal in sesuai dengan hasil penelitian dari BPS bahwa pada tahun 2017 bahwa 40\% lapisan masyarakat sedang tertekan atau krisis dan memastikan daya beli masyarakat rendah. Perlambatan daya beli tidak hanya pada sektor fashion tetapi di subsektor lain juga mengalami penurunan daya beli masyarakat. Berdasarkan hasil survei BPS dan peneliti terdahulu adanya penurunan daya beli masyarakat di latar belakangi oleh inflasi di Januari 2017 menunjukan angka 0,97\% sedangkan pada September 2017 tingakat inflasi berada di level $0,13 \%$ dan melambatnya tingkat permintaan domestik tahun ini. Alasan kedua penurunan daya beli berdasarkan wawancara kepada pelaku usaha UMKM di Kota Bandung yaitu perubahan pola konsumsi yang bisanya masyarakat lebih memiliki produk untuk jangka panjang beralih memilih hanya untuk mendapatkan pengalaman, selain itu lapangan kerja sektor formal semakin menyusut yang menyebabkan banyaknya yang beralih profesi ke sektor informal sehingga berdampak pada pendapatannya, juga peralihan bisnis online yang menimbulkan PHK besar-besaran. Hal tersebut menimbulkan keunggulan bersaing yang lebih ketat.

Adapun fenomena permasalahan secara spesifik yang terjadi dilapangan sebagai berikut :

1. Turnover produk yang lambat dikarenakan sebagian besar para pelaku Usaha Kecil Menengah belum optimal memanfaatkan teknolongi.

2. Kurangnya kreativitas sumber daya manusia dalam menghasilkan produk baru yang inovatif dan konsisten.

3. Tidak dapat mempertahankan pelanggan-pelanggan yang potensial sehingga beralih kepada kompetitor.

4. Tidak memberikan produk pengganti sebagai jaminan atas klam konsumen.

Sesuai dengan beberapa fenomena di atas setiap pelaku bisnis UMKM sektor fashion di Kota Bandung dituntut untuk memiliki strategi bisnis untuk mempertahankan keunggulannya dalam bersaing. Strategi ini dapat diterapkan oleh UMKM sebagai agen of change dalam menghadapi persaingan yang kompetitif. Strategi bisnis yang dapat diterapkan dalam peneltian ini diambil dari strategi bisnis generik menurut Porter (1994); Wheelen dan David (2010) meliputi Cost Leadership Strategy, Differentiation Strategy, Focus Strategy, dan Leadership/ Differentiation integrated. Teori 
tersebut diambil dalam penelitian ini dikarenakan dapat diimplementasikan di industri kecil maupun industri besar. Secara umum melihat hasil penelitian terdahulu bahwa strategi bisnis memiliki pengaruh yang positif dan singnifikan dalam keunggulan bersaing. Oleh karena itu variabel keunggulan bersaing diambil menurut (Wickham, 2001;Barney,2011;Jones, 2003) menjelaskan bahwa keunggulan bersaing memperhatikan keunikan produk/layanan, variasi produk/layanan, harga/nilai produk, citra, kualitas pelayanan, dan saluran distribusi. Penelitian ini berfokus pada klasifikasi Usaha Kecil Menengah di Kota Bandung. Penjelasan di atas menunjukan pentingnya strategi dalam keunggulan bersaing dapat memberikan alternatif-alternatif lain yang membedakan dengan kompetitornya dengan menerapkan nilai inovasi yang unik di benak pelanggan.

\section{Kajian Literatur}

\subsection{Strategi Bisnis}

Strategi dimulai dengan konsep bagaimana menggunakan dan mengimplementasikan sumberdaya perusahaan secara paling efektif dalam lingkungan perusahan baik ekternal maupun internal yang sering berubah-ubah. Bisnis pada umumnya merupakan unit organisasi yang memiliki strategi bisnis yang berbeda dan manajer dengan penjualan dan tanggung jawab dalam meraih keuntungan, Aaker (2005: 4). Selain itu strategi terpadu ialah semua bagian dari rencana itu serasi satu sama dan bersesuaian. Strategi diterapkan untuk mencapai suatu tujuan perusahaan dalam jangka pendek maupun jangka panjang. Sedangkan menurut Wheelen, dan David (2010 : 120) strategi adalah tujuan, yang diambil sebelum mengambil suatu tindakan, dan menunjukkan pemahaman bersama tentang visi dan misi perusahaan. Strategi bisnis perusahaan adalah pilihan yang sengaja dibuat tentang bagaimana perusahaanakan melakukan aktivitas utama dan mandukung rantai nilai untuk menciptakan nilai unik. tujuan dari strategi tingkatan bisnis adalah untuk menciptakan perbedaan antara posisi perusahaan dan pesaing-pesaingnya yang dapat memiliki nilai lebih bagia pelanggan. Wheelen, dan David (2010 : 121) .

Kesimpulan dari pendapat para ahli diatas bahwa strategi adalah suatu rencana perusahaan yang dapat dilihat dari visi dan misi perusahaan sebagai petunjuk yang dirancang sebagai tujuan utama dari suatu perusahaan melalui pelaksanaan yang tepat sebagai suatu proses penentuan rencana pemimpin puncak yang berfokus pada tujuan jangka panjang organisasi, disertai penyusunan suatu cara atau upaya bagaimana agar tujuan tersebut dapat dicapai. Beberapa hal yang harus diperhatikan perusahaan saat memilih strategi bisnis adalah siapa yang akan dilayani, apa kebutuhan target pelanggan tersebut agar bisa memuaskan, dan bagaimana kebutuhan itu akan terpenuhi. Hal ini dikarenakan persaingan di Usaha Mikro Kecil dan Menengah telah menciptakan banyak pilihan menarik bagi pelanggan, sehingga mempersulit menentukan strategi untuk melayani mereka dengan sebaik-baiknya. Maka dari itu perusahaan dapat menenntukan strategi bisnis mana yang dapat diintegrasikan kedalam aktivitas bisnisnya (Aaker, 2005: 4; Wheelen dan David, 2010).

Setiap strategi bisnis membantu perusahaan untuk membangun dan memanfaatkan keunggulan kompetitif tertentu dalam lingkup persaingan tertentu. Bagaimana perusahaan mengintegrasikan aktivitas yang mereka lakukan di dalam setiap strategi tingkat bisnis yang berbeda menunjukkan bagaimana perbedaannya satu sama lain.

Efektivitas strategi tingkat bisnis bergantung pada peluang dan ancaman di lingkungan eksternal perusahaan dan pada kekuatan dan kelemahan yang berasal dari portofolio sumber daya perusahaan. Oleh karena itu, penting bagi perusahaan untuk memilih strategi tingkat bisnis yang didasarkan pada kecocokan antara peluang dan ancaman di lingkungan eksternal dan kekuatan organisasi internalnya sebagaimana ditunjukkan oleh kompetensi intinya. Setelah perusahaan memilih strateginya, perusahaan harus secara konsisten menekankan tindakan yang diperlukan agar dapat berhasil.

Berikut merupakan dimensi dari jenis tingkat strategi bisis menurut menurut (Porter, 1994; Wheelen dan David, 2010) sebagai berikut :

\section{1) Strategi Kepemimpinan Biaya}

strategi kepemimpinan biaya adalah seperangkat tindakan terpadu yang dilakukan untuk menghasilkan barang atau jasa dengan harga yang dapat diterima oleh pelanggan dengan yang paling rendah jika dibandingkan dengan pesaing. Perusahaan yang menggunakan strategi kepemimpinan biaya biasanya menjual barang atau jasa standar ke pelanggan industri yang paling khas. Inovasi 
proses, yang merupakan metode dan teknik produksi dan distribusi yang baru dirancang yang memungkinkan perusahaan beroperasi lebih efisien, sangat penting untuk keberhasilan penggunaan strategi kepemimpinan biaya.

\section{2) Strategi Diferensiasi}

Strategi diferensiasi adalah serangkaian tindakan terpadu yang dilakukan untuk menghasilkan barang atau jasa (dengan biaya yang dapat diterima) yang menurut pelanggan berbeda dengan cara yang penting bagi mereka. Sementara pemimpin biaya melayani pelanggan biasa di sebuah industri, pembeda menargetkan pelanggan yang nilainya diciptakan oleh cara produk perusahaan berbeda dari produk yang diproduksi dan dipasarkan oleh pesaing. Inovasi produk, yaitu menghasilkan cara baru untuk memecahkan masalah pelanggan - melalui pengembangan produk atau layanan baru - yang menguntungkan pelanggan.

3) Strategi Fokus

Strategi fokus adalah serangkaian tindakan terpadu yang dilakukan untuk menghasilkan barang atau jasa yang melayani kebutuhan segmen persaingan tertentu. Dengan demikian, perusahaan menggunakan strategi fokus saat mereka memanfaatkan kompetensi inti mereka untuk melayani kebutuhan segmen industri tertentu atau ceruk dengan mengesampingkan orang lain. Contoh segmen pasar spesifik yang dapat ditargetkan oleh strategi fokus meliputi (1) kelompok pembeli tertentu (remaja atau lansia). (2) segmen produk yang berbeda atau (3) pasar geografis yang berbeda.

4) Strategi Kepemimpinan / Diferensiasi Terpadu

Tujuan penggunaan strategi ini adalah untuk secara efisien menghasilkan produk dengan beberapa fitur berbeda. Produksi yang efisien adalah sumber mempertahankan biaya rendah sementara diferensiasi adalah sumber untuk menciptakan nilai unik. Perusahaan yang berhasil menggunakan strategi kepemimpinan / diferensiasi biaya terpadu biasanya beradaptasi dengan cepat terhadap teknologi baru dan perubahan yang cepat di lingkungan eksternal mereka. Bersamaan berkonsentrasi untuk mengembangkan dua sumber keunggulan kompetitif (biaya dan diferensiasi) meningkatkan jumlah kegiatan utama dan dukungan di mana perusahaan harus menjadi kompeten. Perusahaan semacam itu sering memiliki jaringan yang kuat dengan pihak luar yang menyempurnakan beberapa kegiatan utama dan dukungan. Pada gilirannya, memiliki keterampilan dalam jumlah aktivitas yang lebih besar membuat perusahaan lebih fleksibel. Jadi simpulan dari strategi generik menurut para ahli diatas bahwa perusahaan dapat melakukan kombinasi dan diimplementasikan dari berbagai strategi generik.

\subsection{Keunggulan Bersaing}

Keunggulan bersaing pada dasarnya tumbuh dari nilai atau manfaat yang dapat diciptakan persuahaan bagi para pembelinya yang lebih dari biaya yang haraus dikeluarkan perusahaan untuk menciptakannya. Bila persuahaan mampu menciptakan keunggulan melalui salah satu dari keempat strategi generik, maka diharapakan dapat memiliki keunggulan bersaing menurut Tampi dalam Aaker (2015 : 71). Selain itu menurut Dirgantoro (2001 : 159) keunggulan bersaing merupakan perkembangan dari nilai yang mampu diciptakan perusahaan untuk pembelinya.

Simpulan dari beberapa para ahli diatas bahwa keunggulan bersaing merupakan kemampuan perusahaan dalam meningkatkan keterampilan dan sumber daya yang dimilikinya kemudian melakukan tindakan menganalisis kekurangan dan kelebihan yang dimiliki perusahaan untuk dapat mengevaluasi aktivitas bisnsinya. Hal tersebeut akan didapat keunggulan bersaing dari perusahan sejenis ataupun tidak dengan memberikan nilai lebih yang tinggi bagi pembeli, melalui harga yang rendah dari pesaing dengan tidak meninggalkan keunikan/inovasi yang bermanfaat untuk pembeli (Dirgantoro (2001); Tampi (2015); Aaker (1989)) .

Menerapakan tingkat strategi bisnis dalam meningkatkan keunggulan bersaing di Usaha Keci Menengah hal ini sesuai dengan penelitian Ferdinand (2003) yang menyatakan bahawa salah satu strategi yang berperan dalam keunggulan bersaing adalah strategi diferensiasi sehingga perusahaan dapat memiliki posisi keunikan yang dikembangkan. Selain itu menurut Kotler (2006) menjelaskan bahwa keunggulan bersaing sebuah perusahaan salah satunya adalah perbedaan (diferensiasi) tawaran perusahaan yang akan memberikan nilai lebih kepada konsumen dibandingkan dengan pesaingnya. Namun, dalam hal berbeda tidak asal berbeda lalu memiliki keunggulan dengan pesaing. Memerlukan implementasi dari tingkatan strategi bisnis mana yang dapat di jalankan oleh perusahaan sesuai 
dengan kondisi pasar, kebutuhan masyarakat, dan sumber daya yang dimiliki oleh perusahaanya melalui pendekatan melalui sudut pandang yang akan dilihat hubungan sebab akibat dengen dimensidimensi keunggulan bersaing sebagai berikut (Porter, 1994; Barney, 2011; Kotler 2007):

1. Keunggulan Produk

2. Keunggulan Kualitas Pelayanan

3. Keunggulan Personalia

4. Keunggulan Citra

5. Keunggulan Saluran Distribusi

\subsection{Kerangka Pemikiran}

Faktor pendukung dari konsep strategi bisnis ini dihubungkan dengan teori Porter (1994) yang meliputi faktor cost leadership strategy, differentiation strategy, focus strategy dan differentiation/leadership integrated. Teori ini di ambil sebagai dimensi dari variabel strategi bisnis karena dapat diimplementasikan di industri kecil dan industri besar secara umum. Faktor pendukung variabel keunggulan bersaing meliputi produk, harga, personalia, citra, kualitas pelayanan, dan saluran distribusi yang diambil menurut beberapa teori (Porter, 1994; Barney, 2011; Kotler 2007).

\begin{tabular}{|c|c|}
\hline $\begin{array}{l}\quad \text { Strategi Bisnis } \\
\text { - } \quad \text { Strategi Kepemimpinan Biaya } \\
\text { - } \quad \text { Strategi Differensiasi } \\
\text { - } \quad \text { Strategi Fokus } \\
\text { - } \quad \text { Strategi Terpadu } \\
\text { (Porter, 1994; Wheelen\& Hunger, 2013; } \\
\text { David, 2010 ) }\end{array}$ & $\begin{array}{l}\text { Keunggulan Bersaing } \\
\text { - } \quad \text { Produk } \\
\text { - } \quad \text { Harga } \\
\text { - } \quad \text { Sumber Daya Manusia } \\
\text { - } \quad \text { Citra } \\
\text { - } \quad \text { Kualitas Pelayanan } \\
\text { - Saluran Distribusi } \\
\text { (Porter, 1994; Barnney, 2011; } \\
\text { Kotler, 2007) }\end{array}$ \\
\hline
\end{tabular}

Gambar 2. Kerangka Pemikiran

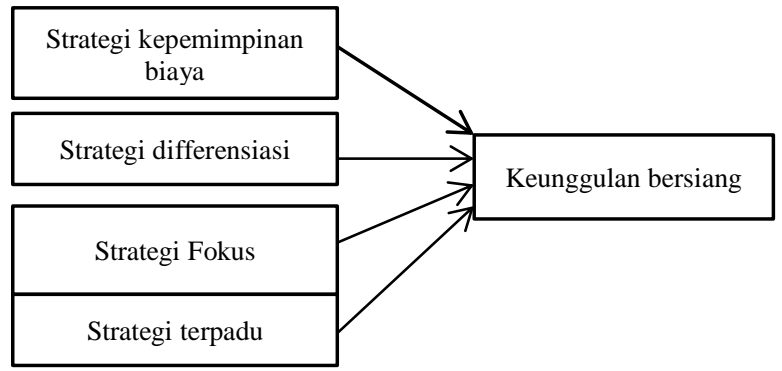

Gambar 3. Paradigma Penelitian

Hipotesis yang dilakukan dalam penelitian ini dapat diketahui debagai berikut :

H1 : Strategi kepemimpinan biaya terdapat pengaruh positif dan signifikan terhadap keunggulan bersaing.

$\mathrm{H} 2$ : Strategi differensiasi berperan positif dan signifikan terhadap keunggulan bersaing

H3 : Strategi fokus berperan positif dan signifikan terhadap keunggulan bersaing.

H4 : Strategi terpadu berperan positif dan signifikan terhadap keunggulan bersaing.

\section{Metode Penelitian}

Pada penelitian ini yang menjadi subjek penelitian adalah para pelaku bisnis Usaha Kecil Menengah Sektor Fashion dan yang menjadi objek penelitian yaitu strategi bisnis dalam keunggulan bersaing di Usaha Kecil Menengah Kota Bandung pada Sektor Fashion. Jumlah populasi UMKM sektor fashion di Kota Bandung sebanyak 507 periode (2010-2017). Berdasarkan rumus Slovin jumlah sampel pada 
penelitian ini sebanyak 223 responden atau 74 UMKM. Analisis data yang dilakukan pada penelitian ini diantaranya adalah analisis regresi berganda.

Pengukuran validitas dan reabilitas ini diajukan pada semua responden, yaitu 223 responden. Hasil dari uji validitas variabel strategi bisnis menunjukan data (valid) atau kuisioner yang digunakan dapat diterima dan layak digunakan. Standar kelayakan untuk memenuhi data validitas dengan $r>0,3$ menurut Sugiono (2013) dan uji reabilitas dengan Cronbach's Alpha > 0,6 menurut Sekaran (2006).

Metode penelitian yang digunakan deskriptif kuantitatif dengan teknik pengumpulan data menggunakan kuisioner dan wawancara. Data yang telah dikumpulkan akan diolah dengan menggunakan software SPSS versi 22,00.

\section{Hasil dan Pembahasan}

\subsection{Analisis Deskriptif}

Dimensi yang memiliki mean terbesar adalah dimensi strategi kepemimpinan biaya/differensiasi terpadu sebesar 3,89 yang tergolong "tinggi" diantara dimensi strategi bisnis lainnya, dimensi mean terendah adalah strategi kepemimpinan biaya yaitu 3,69 dan juga strategi fokus yaitu 3,76 termasuk kategori "cukup tinggi". Nilai standar deviasi dari variabel strategi bisnis ini berada di bawah $20 \%$ dari rata-rata, yaitu sebesar 7,7\% dilihat dari nilai (standar deviasi : mean)x 100\% menurut Santoso (2012) yang menunjukan bahwa jawaban responden memiliki tingkat variasi yang rendah.

Tabel 2. Deskriptif Strategi Bisnis

\begin{tabular}{|l|c|c|c|c|c|}
\hline \multicolumn{1}{|c|}{ Dimensi } & N & Min & Max & Mean & Std. Deviation \\
\hline Strategi Kepemimpinan Biaya & 193 & 2 & 5 & 3,69 & 0,548 \\
\hline Strategi Differensiasi & 193 & 2 & 5 & 3,81 & 0,471 \\
\hline Strategi Focus & 193 & 3 & 5 & 3,76 & 0,431 \\
\hline Strategi Terpadu & 193 & 2 & 5 & 3,89 & 0,547 \\
\hline Strategi Bisnis & $\mathbf{1 9 3}$ & $\mathbf{3}$ & $\mathbf{4}$ & $\mathbf{3 , 7 9}$ & $\mathbf{0 , 2 9 4}$ \\
\hline
\end{tabular}

Secara keseluruhan dimensi strategi kepemimpinan biaya termasuk ke dalam kategori "tinggi" karena memiliki mean 3,69. Indikator yang memiliki mean terbesar adalah strategi kepemimpinan biaya 5 yang berarti perusahaan memiliki kuatilas produk yang tinggi. Sementara itu, strategi kepemimpinan biaya dengan mean terendah terdapat pada indikator strategi kepemimpinan biaya 1 sebesar 3,31 yang tergolong kategori "cukup tinggi". Indikator ini menjelaskan perusahaan memiliki biaya produksi rendah. Secara keseluruhan standar deviasi pada dimensi strategi kepemimpinan biaya sebesar 0,548 atau $14,8 \%$ dilihat dari nilai (standar deviasi : mean)x 100\%. Angka tersebut masih berada di bawah $20 \%$ yang artinya responden memiliki tingkat variasi jawaban yang rendah, Santoso (2012).

Secara keseluruhan dimensi strategi differensiasi tergolong kategori "tinggi" dengan mean sebesar 3,81 . Indikator yang memiliki mean terbesar adalah strategi differensiasi 5 yang menjelaskan perusaan memberikan kualitas pelayanan yang berbeda dengan pesaing. Sementara itu indikator terendah pada tipe strategi differensiasi 2 sebesar 3,26 yang tergolong "rendah". Hal ini berarti produk perusahaan mudah di tiru oleh pesaing. Secara keseluruhan standar deviasi pada dimensi strategi differensiasi adalah sebesar 0,471 atau $12,3 \%$, dilihat dari nilai (standar deviasi : mean) x 100\% mengandung arti tingkat variasi jawaban responden rendah.

Secara keseluruhan dimesi strategi fokus termasuk ke dalam kategori "tinggi" karena memiliki mean 3,76. Indikator yang memiliki mean terbesar adalah indikator strategi fokus 4 yang berarti perusahaan berfokus pada target pasarnya. Sementara itu, strategi fokus dengan mean terendah terdapat pada indikator strategi fokus 1 sebesar 3,42 yang tergolong kategori "cukup tinggi". Indikator ini menjelaskan perusahaan tidak memiliki identitas produk yang berbeda. Secara keseluruhan standar deviasi pada dimensi strategi fokus sebesar 0,431 atau 11,4\% menurut Santoso (2012) dilihat dari nilai (standar deviasi : mean) x 100\%. Angka tersebut masih berada di bawah $20 \%$ yang artinya responden memiliki tingkat variasi jawaban yang rendah. 
Secara keseluruhan strategi terpadu temasuk dalam kategori tinggi kerena memiliki mean sebesar 3,89. Indikator yang memiliki mean terbesar adalah strategi terpadu 1 yaitu 4,41 tergolong kategori "sangat tinggi" dimana indikator strategi terpadu 1 menjelaskan bahwa perusahaan menjaga hubungan baik antara pelanggan dan pemasok. Tidak jauh berbeda dengan indikator strategi terpadu 5 yaitu perusahaan telah mengetahui target pasarnya yang memiliki mean 4,23 tergolong kategori "sangat tinggi". Namun, terdapat indikator terendah yaitu strategi terpadu 2 yang menjelaskan bahwa perusahaan sebagian besar tidak melakukan ekspansi. Angka mean menunjukan 3,40 tersebut masuk dalam kategori "cukup tinggi". Secara keseluruhan standar deviasi pada dimensi strategi fokus sebesar 0,547 atau $14 \%$. Angka tersebut masih berada di bawah $20 \%$ dilihat dari (standar deviasi : mean) $\mathrm{x}$ $100 \%$ menurut Santoso (2012) artinya responden memiliki tingkat variasi jawaban yang rendah.

Tabel 3. Deskriptif Keunggulan Bersaing

\begin{tabular}{|l|r|r|r|r|r|}
\hline \multicolumn{1}{|c|}{ Indikator } & \multicolumn{1}{c|}{ N } & \multicolumn{1}{c|}{ Min } & \multicolumn{1}{c|}{ Max } & \multicolumn{1}{c|}{ Mean } & \multicolumn{1}{c|}{ Std. Deviation } \\
\hline Keunggulan Produk & 193 & 1 & 5 & 3,85 & 0,618 \\
\hline Keunggulan Harga & 193 & 3 & 5 & 3,81 & 0,547 \\
\hline Keunggulan Personalia & 193 & 1 & 5 & 4,17 & 0,661 \\
\hline Keunggulan Citra & 193 & 2 & 5 & 4,17 & 0,521 \\
\hline Keunggulan Kualitas Pelayanan & 193 & 3 & 5 & 3,96 & 0,628 \\
\hline Keunggulan Saluran Distribusi & 193 & 2 & 5 & 3,91 & 0,655 \\
\hline Keunggulan Bersaing & $\mathbf{1 9 3}$ & $\mathbf{3}$ & $\mathbf{5}$ & $\mathbf{3 , 9 8}$ & $\mathbf{0 , 3 7 7}$ \\
\hline
\end{tabular}

Dapat dilihat dari tabel 3, secara umum keunggulan bersaing memiliki mean sebesar 3,98. Angaka tersebut menunjukan bahwa keunggulan bersaing pada UMKM fashion di Kota Bandung termasuk dalam kategori "tinggi". Indikator yang memiliki nilai mean tertinggi adalah indikator keunggulan personalia dan keunggulan citra dengan mean sebesar 4,17 termasuk kedalam kategori "tinggi". Selain itu dimensi yang memiliki mean terendah adalah indikator keunggulan harga sebesar 3,81 namun, termasuk kategori "tinggi". Secara keseluruhan, nilai standar deviasi pada variabel keunggulan sebesar 0,377 atau 9,4\%. Hal ini berarti responden memiliki variasi jawaban yang rendah.

\subsection{Hasil Analisis Korelasi}

Berdasarkan hasil analisis korelasi bahwa nilai korelasi antara variabel strategi bisnis dengan variabel keunggulan bersaing adalah sebesar 0,421 angaka ini terdapat pada interval 0,40-0,599 yang berarti strategi bisnis dengan keungglan bersaing memiliki hubungan positif yang sedang. Nilai korelasi pearson nilai menunjukan positif, maka hubungan antara variabel strategi bisnis dengan variabel keunggulan bersaing adalah searah, yang berarti jika strategi bisnis meningkat maka akan diikuti oleh keunggulan bersaing. Dapat diketahui hubungan strategi bisnis dengan keunggulan bersaing signifikan atau tidak, maka dapat dilakukan uji signifikasi dengan uji hipotesis. Dapat dilihat signifikasi hasil korelasi antara strategi bisnis dengan keunggulan bersaing menunjukan angka 0,000.

\subsection{Hasil Analisis Regresi Linier}

Analisis regresi linier digunakan untuk memprediksi bagaimana perubahan nilai strategi bisnis jika nilai keunggulan bersaing pada Usaha Kecil Menengah sektor fashion di Kota Bandung dinaikan atau diturunkan. Sehingga memperoleh persamaan regeresi dari penelitian mengenai pengaruh strategi bisnis terhadap keunggulan bersaing dapat dilihat pada tabel 4.12 dapat diketahui konstanta (a) bernilai 2,134, koefisien regresi -106 (b1), koefisien regresi sebesar 0,191(b2), koefisiensi regresi 0,196(b3) dan koefisiensi regresi 0,197(b4).

$$
\mathrm{Y}=\mathrm{a}+\mathrm{b} 1 \mathrm{x} 1+\mathrm{b} 2 \times 2+\mathrm{b} 3 \times 3+\mathrm{b} 4 \times 4
$$

$$
\mathrm{Y}=2,134-0,106 \mathrm{x}+0,191 \mathrm{x}+0,196 \mathrm{x}+0,197 \mathrm{x}
$$

Keterangan : 
a. Konstanta 2,134 dapat diartikan, jika strategi bisnis bernilai $(\mathrm{X}=0)$ maka keunggulan bersaing yang tercapai sebesar 2,134.

b. Strategi kepemimpinan biaya memiliki nilai koefisien regresi linear sebesar -0,106 maka ini berarti setiap penambahan satu angka strategi bisnis dengan koefisien bernilai negatif, antara strategi kepemimpinan biaya dengan keunggulan bersaing. Koefisien bernilai negatif artinya semakin naik strategi kepemimpinan biaya maka semakin menurun tingkat keunggulan bersaing.

c. Strategi differensiasi memiliki nilai koefisiensi linear sebesar 0,191 artinya setiap penambahan satu angka strategi differensiasi dengan koefisien berniali positif antara strategi differensiasi dengan keunggulan bersaing. Koefisiensi positif artinya terjadi hubungan positif antara strategi differensiasi dengan keunggulan bersaing, semakin naik strategi differensiasi maka semakin meningkat keunggulan bersaingnya.

d. Strategi fokus memiliki nilai koefisiensi linear sebesar 0,196 artinya setiap penambahan suatu angka strategi fokus dengan koefisiensi bernilai positif antara strategi fokus dengan keunggulan bersiang, semakin naik strategi fokus dengan keunggulan bersiang maka semakin meningkatkan keunggulan bersaing.

e. Strategi kepemimpinan/differensiasi terpadu memiliki nilai koefisiensi sebesar 0.197. Artinya setiap penambahan satu angka strategi kepemimpinan/differensiasi terpadu bernilai positif dengan keunggulan bersiang, semakin naik strategi kepemimpinan/differensiasi terpadu maka semakin meningkat keunggulan bersaing.

\subsection{Koefisiensi Determinasi}

Berdasarkan tabel 4 nilai koefisiensi determinasi (R Square/R2) adalah sebesar 0,333 atau 33,3\% perubahan nilai strategi bisnis dapat dijelaskan oleh strategi kepmimpinan biaya, strategi differensiasi, strategi fokus, strategi terpadu. Sisanya sebesar $67,7 \%$ dipengaruhi oleh hal lain yang tidak diteliti dalam penelitian ini. Koefisiensi determinasi untuk menjawab pertanyaan yang ketiga, yaitu seberapa besar peran strategi bisnis terhadap keunggulan bersaing yang diukur oleh strategi kepemimpinan biaya, strategi differensiasi, strategi fokus, strategi terpadu.

Tabel 4. Hasil Analisis Koefisien Determinasi

\begin{tabular}{|c|c|c|c|c|}
\hline Model & R & R Square & Adjusted R Square & Std. Error of the Estimate \\
\hline 1 & $0,577^{\mathrm{a}}$ & 0,333 & 0,319 & 0,312 \\
\hline
\end{tabular}

\subsection{Uji Hipotesis}

Berdasarkan tabel 5 dapat dilihat bahwa angka signifikan sebesar 0.000. Nilai tersebut lebih kecil bila dibandingkan dengan nilai (Fo) yang dilihat pada kolom $F$ yang besarannya 23,462 dengan menggunakan tingkat signifikansi 0,05. Maka model regeresi dalam penelitian ini dapat diterima.

Tabel 5. Hasil Uji F

\begin{tabular}{|l|l|c|c|c|c|c|}
\hline \multicolumn{2}{|c|}{ Model } & Sum of Squares & Df & Mean Square & F & Sig. \\
\hline \multirow{2}{*}{1} & Regression & 9,107 & 4 & 2,277 & 23,462 & $0,000^{\mathrm{b}}$ \\
\cline { 2 - 7 } & Residual & 18,243 & 188 & 0,097 & & \\
\cline { 2 - 8 } & Total & 27,350 & 192 & & & \\
\hline
\end{tabular}

Nilai t hitung strategi bisnis terhadap keunggulan beresaing sebesar 6,409 sementara untuk t tabel untuk signifikansi 0,05 . Begitupun dengan angka signifikansi yang menunjukan nilai 0,000 yang berarti lebih kecil dari 0,005. Demikian Ho ditolak dan Ha diterima. Hal ini berarti terdapat peran yang positif dan signifikan antara stratregi bisnis dalam keunggulan bersaing. Adapun peranan atau kontribusi secara parsial dengan didasarkan pada pengambilan keputusan pada uji $\mathrm{T}$ dengan tingkat signifikasi 0,05 hasil yang didapat adalah :

1. Jika nilai signifikan $>0,05$ maka hipotesis ditolak (koefisiensi regresi tidak signifikan).

2. Jika nilai signifikan $\leq 0,05$ maka hipotesis diterima (koefisiensi regresi signifikan). 
3. Jika $\mathrm{t}$ tabel $<\mathrm{t}$ hitung maka variabel independen secara individu tidak berpengaruh terhadap variabel dependen.

4. Jika $>t$ tabel maka secara independen secara individu berpengaruh terhadap variabel dependen.

Tabel 6. Hasil Uji T

\begin{tabular}{|l|l|l|l|l|l|l|}
\hline \multirow{3}{*}{ Model } & \multicolumn{2}{|c|}{ Unstandardized Coefficients } & \multicolumn{2}{|c|}{$\begin{array}{c}\text { Standardized } \\
\text { Coefficients }\end{array}$} & t & Sig. \\
\cline { 2 - 8 } & \multicolumn{1}{|c|}{ B } & \multicolumn{1}{|c|}{ Std. Error } & \multicolumn{2}{|c|}{ Beta } & & \\
\hline \multirow{4}{*}{1} & (Constant) & 2,134 & 0,293 & & 7,284 & 0,000 \\
\cline { 2 - 8 } & Strategi Kepemimpinan Biaya & $-0,106$ & 0,043 & $-0,154$ & $-2,461$ & 0,015 \\
\cline { 2 - 8 } & Strategi Differensiasi & 0,191 & 0,056 & 0,239 & 3,440 & 0,001 \\
\cline { 2 - 8 } & Strategi Fokus & 0,196 & 0,059 & 0,223 & 3,326 & 0,001 \\
\cline { 2 - 7 } & Strategi Terpadu & 0,197 & 0,044 & 0,286 & 4,467 & 0,000 \\
\hline
\end{tabular}

Berdasarkan tabel 6 diperoleh nilai t hitung sebesar -2,461 untuk strategi kepemimpinan biaya, 3,440 untuk strategi differensiasi,3,326 untuk strategi fokus dan 4,467 untuk strategi terpadu. Dengan rumus $\mathrm{df}=$ jumlah data -1 atau sebesar $193-1=192$, maka diperoleh $\mathrm{t}$ tabel sebesar 1,9724. Berdasarkan data tersebut, diperoleh nilai t hitung untuk strategi kepemimpinan biaya lebih kecil dari $\mathrm{t}$ tabel $(-2,461>1,9724)$, strategi differensiasi memiliki nilai $\mathrm{t}$ hitung lebih besar dari $\mathrm{t}$ tabel $(3,440>$ 1,974), strategi fokus memiliki nilai t hitung lebih besar dari t tabel $(3,326>1,974)$ dan strategi terpadu memiliki nilai t hitung lebih besar dari $t$ tabel $(4,467>1,974)$.

Angka signifikasi pada kolom Sig untuk strategi kepemimpiann biaya 0,015, angka sig pada strategi differensiasi 0,001 , angka sig pada strategi fokus 0,001 dan angka sig pada strategi terpadu 0,000 . Angka signifikan tersebut nilainya lebih kecil jika dibandingkan dengan nilai probabilitasnya sebesar 0,05 atau 5\%. Maka dari itu mengacu pada pendapat Gozali (2013) yang menyatakan hipotesis menunjukan hipotesis diterima apabila t hitung $>\mathrm{t}$ tabel dan tingkat signifikasi $<0,05$. Hal tersebut menunjukkan strategi kepemimpinan/differensiasi terpadu yang berperan signifikan secara positif kuat terhadap keunggulan bersaing pada Usaha Kecil Menengah sektor fashion di Kota Bandung.

Tabel 7. Hasil Uji Hipotesis

\begin{tabular}{|l|l|l|l|}
\hline No & \multicolumn{1}{|c|}{ Hasil Pembahasan } & Nilai Cr dan P & \multicolumn{1}{|c|}{ Keterangan } \\
\hline 1 & $\begin{array}{l}\text { Strategi kepemimpinan biaya berperan positif } \\
\text { dan signifikan terhadap keunggulan bersaing di } \\
\text { UMKM fashion Kota Bandung }\end{array}$ & $\begin{array}{l}\mathrm{Cr}: 2,461 \\
\mathrm{P}: 0,015\end{array}$ & Diterima \\
\hline 2 & $\begin{array}{l}\text { Strategi differensiasi berperan positif dan } \\
\text { signifikan terhadap keunggulan bersaing di } \\
\text { UMKM fashion Kota Bandung }\end{array}$ & $\begin{array}{l}\mathrm{Cr}: 3,440 \\
\mathrm{P}: 0,001\end{array}$ & Diterima \\
\hline 3 & $\begin{array}{l}\text { Strategi fokus berperan positif dan signifikan } \\
\text { terhadap keunggulan bersaing di UMKM } \\
\text { fashion Kota Bandung }\end{array}$ & $\begin{array}{l}\mathrm{Cr}: 3,326 \\
\mathrm{P}: 0,001\end{array}$ & Diterima \\
\hline 4 & $\begin{array}{l}\text { Strategi Kepemimpinan biaya/differensiasi } \\
\text { terpadu berperan positif terhadap keunggulan } \\
\text { bersaing di UMKM fashion Kota Bandung }\end{array}$ & $\begin{array}{l}\mathrm{Cr}: 4,467 \\
\mathrm{P}: 0,000\end{array}$ \\
\hline
\end{tabular}

\section{Kesimpulan dan Saran}

\subsection{Kesimpulan}

UMKM di Kota Bandung yang bergerak dalam industri kreatif sektor fashion sudah dapat mengaplikasikan strategi bisnisnya diartikan bahwa strategi tersebut dikarenakan adanya keunggulan citra melalui reputasi yang baik kepada pelanggan, keunggulan kualitas pelayanan yang memenuhi kebutuhan pelanggan, keunggulan produk yang inovatif, biaya produksi yang rendah dengan cara menerapkan metode amati, tiru, modifikasi (Metode ATM) dan harga jual yang diberikan dapat 
terjangkau sesuai kualitas produk yang dijualnya, meskipun belum optimal dan masih mengikuti ratarata harga pasar sehingga tidak jauh berbeda dengan pesaing. Selain itu, keunggulan sumber daya manusia yang sudah cukup tinggi meskipun belum memaksimalkan kopetensi karyawan secara menyeluruh dengan kurangnya kreativitas dan pengetahuan mengenai kewirausahaan.

Tingkat Keunggulan bersaing di UMKM fashion Kota Bandung tergolong kategori "tinggi". Namun, masih ada indikator yang perlu ditingkatkan kembali yaitu keunggulan harga dan produk. Demikian temuan ini bermakna bahwa UMKM fashion di Kota Bandung rata-rata tidak memiliki pembeda atau tidak bersaing di harga dan produk tetapi bersang di keunggulan kualitas pelayanan, citra, dan juga saluran distribusi yang dapat di lihat bahawa indikator tersebut memiliki nilai mean dengan kategori "tinggi " dari pada indikator keunggulan bersaing lainnya.

Selain itu penelitian ini juga menemukan adanya pengaruh positif dan signifikan antara strategi bisnis terhadap keunggulan bersaing. Hasil penelitian membuktikan penetian ini dapat di terima antara strategi bisnis dengan keunggulan bersaing. Berarti UMKM fashion di Kota Bandung perlu menggali, mengenali, dan mampu menentukan dengan tepat apa yang sebenarnya menjadi sumber keunggulan mereka dalam persaingan.

\subsection{Saran}

Saran yang dapat diberikan yaitu dengan cara sebagai berikut:

1. Meningkatkan kemampuan karyawan dengan mengikut sertakan pelatihan mengenai kewirausahaan.

2. Dapat mengikuti perkembangan teknologi seperti misalnya penggunaan media sosial yang efektif sehingga memudahkan proses penjualan produk dan peningkatan penjualan produk, harga yang di jual dapat bersaing dengan cara menetapkan harga murah sesuai dengan target pasar dan kemampuan masyarakat dalam membeli produk yang kita jual.

3. Strategi kepemimpinan biaya masih kurang diaplikasikan oleh UMKM fashion di Kota Bandung. Hal ini bisa menjadi bahan pertimbangan para pelaku UMKM dalam melakukan analisis terhadap pelung atau kesempatan dari lingkungan eksternal dan menyarankan sebaiknya para pelaku UMKM mengetahui perkembangan dan perubahan kondisi perekonomian.

4. Melakukan inovasi-inovasi produk maupun layanan yang memiliki ciri khas dan memberikan nilai manfaat yang lebih di benak pelanggan untuk menciptakan keunggulan yang berkelanjutan dan menjadi market leader.

\section{Daftar Pustaka}

Aaker, D. A. (2005). managing Assets and Skills : A Key to a Sustainable Competitive Advantage. Carnifornia Management, vol 31, hal 91-106.

Aker, D. A. (2005). Strategic Market Management, Seventh Edition. united Stated America.

Ambarwati, S. D. (2003). Upaya Membangun Brand Image dan Bran equity melalui Kegiatan Periklanan yang Efektif . STIE Widya Winata, No. 29 (Mei-Agustus).

Barney, B. j. (2011). Gaining and Sustaining Competitive Advantage, Fourth Edition. Pearson.

Chittithaworn, C. (2011). Factors of Small \& Medium Enterprises (SMEs) in Thailand. . Asian Social Science., Vol.7, No.5; May.

Darmawan, D. (2013). Metode Penelitian Kuantitatif. Bandung: PT Remaja Rosdakarya.

David, F. R. (2006). Strategic Management, terjemahan. Jakarta: Salemba Empat .

Delmas. (2000). Nilai-nilai Differensiasi pada Perusahaan Kecil dan Menengah. Jakarta.

Dhewanto, W. (2015). Manajemen Inovasi . Yoogyakarta: CV Andi Offset .

Dirgantoro , C. (2001). Manajemen Stratejik: Konsep Khusus dan Implementasi . Jakarta, Indonesia: PT Gramedia Widiasarana Indonesia.

Ferdinand, A. (2003). Sustainable Competitive Advantage : Sebuah Eksplorasi Model Konseptual. Semarang : Universitas Diponogoro .

Harapan, K., Sam'un, J. R., \& Oekan, S. A. (2017). Effect of Product Differentiation Implementation on Marketing Performance on Apparel Indusstri in Bandung City . IOSR Journal of Business and Management, (IOSR-JBN) e-ISSN : 2278-487X, p-ISSN: 2319-7668. Vol, 19. Issue 5, Ver. II (May 2017), PP 41-50 . 
Ibrahim , R. (2015). Influance of Strategic Competitive Performance. United Kongdom, Vol, III. Issue 4, April.

Istanto, Y. (2010). Pengaruh Strategi Keunggulan Bersaing dan Positioning terhadap Kinerja (Survey pada Koperasi Serba Usaha di Kabupaten Sleman Yogyakarta . Buletin Ekonomi, Vol, 8. No 2, Agustus. Hal 70- 170.

Jogiyanto . (2011). Pedoman Survei Kuesioner : Pengembangan Kuesioner, Mengatasi Bias dan Meningkatkan Respon. BPFE, Yogyakarta.

Jones, O., \& Tilley, F. (2003). Competitive Advantage in SMEs, Organising for Innovation and Change . British Library : Manchester metropolitan University .

Kotler, \& Keller. (2007). Manajemen Pemasaran, Edisi 12, Jilid 1. Jakarta: PT Indeks .

Kotler, P., \& Gary, A. (2003). Dasar-dasar Pemasaran, Jilid 1, Edisi ke-9. Jakarta: PT Indeks Gramedia.

Kotler, P., \& Keller, K. L. (2016). Marketing Management 15 th Edition . Pearson Education .

Kotler, P. (2002). Manajemen Pemasaran, Jilid 1, Edisi Milenium. Jakarta : Prehallindo .

McGraw, H. (1989). Strategic Management and Business Policy, Second Edition . PT Gelora Aksara Pratama : Erlangga.

Merlina, \& Kurniawan. (2016). Pengaruh Strategi Biaya Rendah dan Differensiasi terhadap Keberhasilan PT Tahu Tauhid. Jurnal Manajemen, Vol, 15. No 2, Mei.

Osmani . (2013). Competitive Advantage and its Impact in Small and Medium Enterprises, (SMEs) Case of Albania. European Scientific Journal, Vol 9, No 16, ISSN: 1857-7881, E-ISSN $1857-7431$.

Papulva, E. (2006). Competitive Strategy and Competitive Advantage of Small and Midsized Manufacturing Enterprises in Slovakia. E-leader, Slovakia.

Pongwiritthon , R., \& Awirothananon. (2015). Competitive Advantage of Small and Medium Enterprises in Nortern Thailand . Journal of US-China Public Administration, Vol, 12. No 1. 42-50 doi: 10.17265/1548-6591/2015.01.005.

Porter, M. E. (1994). Keunggulan Bersaing. Jakarta Barat: Binarupa Aksara.

Porter, M. E. (2001). Strategi Bersaing . Jakarta: Erlangga.

Priyanto, D. (2013). Mandiri Belajar Analisis Data dengan SPSS. Yogyakarta: Mediakom.

Santoso , S. (2012). Panduan Lengkap SPSS Versi 20. Jakarta: Media Komputindo .

Santoso , S. (2018). Konsep Dasar dan Aplikasi SEM dengan AMos 24. Jakarta: PT Elex Media Komputindo.

Schilling , M. A. (2013). Manajemen Strategis Inovasi Teknologi Edisi Keempat. Yogyakarta: Pustaka Pelajar.

Sekaran, U. (2006). Metode Penelitian Bisnis. Jakarta: Salemba Empat .

Siregar, S. (2015). Statistik Parametrik untuk Penelitian Kuantitatif dilengkapi dengan Perhitungan Manual dan Aplikasi SPSS versi 17. PT Bumi Aksara.

Stevanus, T. N., Rofiaty, \& Siti , A. (2016). Faktor Lingkungan usaha dan Strategi Bersaing terhadap Keunggulan Bersaing dan Kinerja Usaha (Studi pada UMKM di Kota Malang). Media Mahardhika, Vol 15, No 1 September .

Sugima, A. G. (2008). Metode Riset Bisnis dan Manajemen. Bandung : Gurdaya Inti Marta.

Sugiyono . (2013). Metode Penelitian Kuantitatif, Kualitatif dan R\&D . Bandung: Alfabeta.

Sugiyono . (2013). Statistika untuk Penelitian . Bandung: Alfabeta.

Sulaiman, M., \& Salim. (2011). Organizational Learning Innovation and Performance : A Study of Malaysa Small and Medium Sized Enterprises. Desember: Vol,6. No 12. Desember .

Tampi, N. H. (2015). Analisis Strategi Differensiasi Layanan, dan Differensiasi Citra terhadap Keunggulan Bersaing dan Kinerja Pemasaran (Studi pada PT Telkomsel Grapari Manado). Jurnal EMBA, Vol, 3 No 4 Desember. Hal 68-81.

Thongvanh, S. (2014). The Effect of Enterpreneurial Orientation and Competitive Advantage on SMEs Growth : A Structural Equation Modelling Study. International Journal of Business and Social Science, Vol. 5, No. 6(1) May .

Umar, H. (2005). Strategic Manajemen in Action (Konsep Teori dan Teknik Menganalisis Stategis Berdasarkan Konsep Michael R. Porter; Fred R.David; dan Wheelen Hunger. Jakarta: PT Gramedia Pustaka Utama. 
Wheelen, T., \& David, A. (2001). Strategic management and Business Policy Achieving Sustainability. Twelfth Edition Pearson Education .

Wickham, P. A. (2001). Strategic Enterpreneurship . A Decision Making Approch to New Venture Creation and Management 2 edition. Harlow: Pearson Education .

\section{*Email korespondensi:}

Lindamaryani96@gmail.com 